\title{
Springer Workshop on How to Get Published in a Scientific Journal: Tips from Springer Editors
}

\author{
Nabil Khélifi and Abdullah Al-Amri
}

\author{
Keywords \\ Research paper - Writing - Structure - Academic journals - Cover letter - Reviewers' \\ comments • Editors • Publication
}

Publication must be seen as an important, if not the most important, part of the research process. However, writing research papers for academic journals is not easy and is also very competitive. After producing data and generating ideas from your research, the remaining questions that need to be answered are: how to write a clear and concise paper that attracts the attention of journal editors? How to prepare a cover letter? How to respond to reviewer reports? A Senior Publishing Editor from Springer Nature in Heidelberg, Germany shares his advice on how to effectively write and structure your paper, prepare a cover page and respond to reviewers' comments. Also, an Editor-in-Chief of a Springer journal talks about one of the most frequent routes followed on the journey through the world of scientific publishing-from journal reader to author, reviewer and editor. He shares his experience and his strategy for developing his journal, and how he shapes the connection between the journal and its community. He also provides a clear statement of the journal's policy and how he establishes a workflow for effective and rapid peer review. Lastly, he explains why reviewing has an important role to play, and offers his top tips on breaking into the world of journals: an opportunity to understand what editors like - and what they do not!

\section{N. Khélifi (ه)}

Springer, Heidelberg, Germany

e-mail: nabil.khelifi@springer.com

A. Al-Amri

KSU, Riyadh, Saudi Arabia

\section{Author Biography}

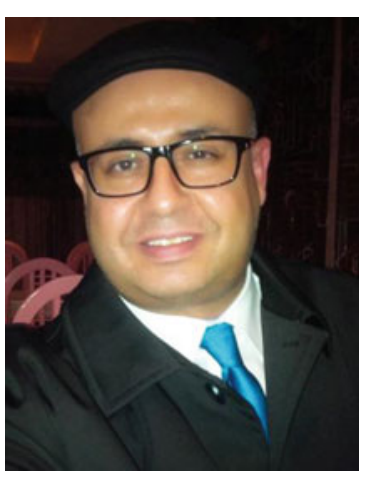

Dr. Nabil Khélifi holds a B.Sc. in Natural Sciences (2001) and an M.Sc. in Earth \& Environmental Sciences (2004) from the University of Sfax (Tunisia). He received fellowships from the global change System for Analysis, Research and Training (START) in 2005 and the German Academic Exchange Service (DAAD) from 2006 to 2010 to continue with his Ph.D. studies in Marine Geosciences (Specialty: Paleo-oceanography and Paleoclimatology) at the University of Kiel in Germany. After completing his Ph.D. in 2010, Dr. Khélifi received a postdoctoral research grant from the German Science Foundation (DFG) to pursue his self-designed research projects at the GEOMAR Ocean Research Centre in Kiel, Germany, which involved reconstructing past changes in oceanography and climate in the North Atlantic and the Mediterranean Sea using marine sediment samples retrieved by the International Ocean Drilling Program (IODP) and applying foraminiferal and geochemical proxy methods. He subsequently published his research findings in prominent scientific journals. Dr. Khélifi also received funding from the European Science Foundation (ESF) and some European universities to co-organize with colleagues from Kiel, Bordeaux and Bristol two Workshops on Pliocene climate in Bordeaux, France (2009) and Bristol, UK (2013). In early 2014 he received the Swiss Government Excellence Scholarship (SGES) to continue with his research projects at the ETH in Zurich, Switzerland. Although his interest in scientific research remained strong, in March 2014 he decided to pursue his career as a Senior Publishing Editor with Springer (a part of Springer Nature) in Heidelberg, Germany. He is mainly responsible for developing Springer's publishing program in the Middle East \& North Africa (MENA). The program currently consists of developing 18 academic journals from the Arab World and publishing numerous scientific books each year. Dr. Khélifi also helps researchers in MENA countries publish their work by delivering educational seminars for authors, reviewers, and journal editors to help improve their publication output and quality. He is also a Visiting Lecturer at the University of Carthage, Tunisia and King Saud University, KSA, where he offers M.Sc./Ph.D. courses on geo-communication/presentations and techniques for publishing papers, and career professional development workshops. Most recently, Dr. Khélifi was awarded the 2016 Africa Green Future Leadership Award in recognition of work contributing to sustainable development by advancing science and promoting publications in Africa and the Middle East. In 2017 Dr. Khélifi launched the first Springer conference dedicated to promoting the Euro-Mediterranean integration process, stressing the vulnerability and need for proactive remediation of the Euro-Mediterranean environment. 